\title{
20. \\ VLADAN DESNICA I \\ ISTORIJA KOTARSKIH USKOKA \\ BOŠKA DESNICE
}

\section{Drago Roksandić}

UDK: 94(497.581)“164/174“(093.2):821.163.42Desnica, V.

Izlaganje na skupu

Sažetak: Desničina shvaćanja povijesti i historiografije pretežno su se s pravom istraživala unutar horizonta njegovih estetičkih nazora i nadasve njegova književnog stvaralaštva. Međutim, sačuvana prepiska sa stricem Boškom iz 1920-ih i 1930-ih godina - koju najvećim dijelom čine Boškova pisma Vladanu - otkriva piščeve historiografske interese, historiografsku kulturu mišljenja, pa i historiografske kompetencije. Nigdje to toliko ne dolazi do izražaja koliko u prepisci iz kasnih 1930-ih godina. Tada je Boško Desnica, pored ostalog, finalizirao svoja dvadesetogodišnja istraživanja arhivskih vrela za povijest ravnokotarskih uskoka od sredine 17. do sredine 18. stoljeća, htijući ih objaviti u izdanju Srpske kraljevske akademije u Beogradu. Pritom je Vladan bio najpažljiviji čitatelj rukopisa zbirke, ali i erudicijski kvalificiran kritičar te, prema prepisci, koautor dijela Predgovora zbirke. U to se može uvjeriti bilo koji upućeniji poznavatelj i Boškova i Vladanova jezika i stila, analizirajući kompozitne karakteristike Predgovora. Međutim, tek intertekstualno propitivanje Vladanovih radova objavljenih u Magazinu Sjeverne Dalmacije, polemika u vezi sa Zimskim ljetovanjem i esejističkih varijacija iz 1950-ih i 1960-ih godina omogućuje rekonstrukciju Vladanovih intervencija i formulacija u objavljenom Predgovoru Istorije kotarskih uskoka, zbirke koja je posmrtno tiskana u izdanju Srpske akademije nauka 1950. i 1951. godine (sv. 1: 1646. 1684. i sv. 2: 1684. - 1749.). Drugo, budući da je Boško umro 1945. godine, otvara se pitanje kakav je eventualno bio Vladanov udio u daljnjim pregovorima s Akademijom, koji su zaključeni prihvaćanjem rukopisa na VI. skupu Odeljenja društvenih nauka SAN od 24. IX. 1948. te objavljivanjem 1950. i 1951. godine. Prema oralnoj tradiciji sačuvanoj među Vladanovim potomcima, Vladan je u vrijeme dok je bio čelni čovjek Pravne službe Ministarstva financija Narodne Republike Hrvatske poduzeo sve što je mogao za osiguravanje potrebne podrške da bi se Istorija kotarskih uskoka tiskala. Upitno je u kakvu je stanju bio rukopis kada ga je Boško Desnica poslao Akademiji uoči Rata i koliko je eventualno trebalo intervenirati nakon Rata da bi bio objavljen te tko je sve u finalnoj redakturi i kako sudjelovao. Istorija kotarskih uskoka još je uvijek jedna od najvažnijih zbirki objavljenih izvora za povijest „morlačke Dalmacije“ u drugoj polovini 17. i prvoj polovini 18. stoljeća, pa spomenuta pitanja imaju daljnje višestruke implikacije.

Ključne riječi: Vladan Desnica, Boško Desnica, Istorija kotarskih uskoka, arhivistika, historiografija 
esničin nenaslovljen predgovor Magazina Sjeverne Dalmacije (1934.) u suštini je sažet u dvjema rečenicama: „Život ovoga kraja, njegove potrebe i njegove duhovne težnje, bar u principu, jednako su važni kao i život, potrebe i težnje ma kojeg drugog kraja. Ali su one, iz raznih uzroka, manje vidne i manje uvažavane. " "Život" su pritom za njega bili kako suvremenost tako i prošlost, pa i budućnost žitelja Sjeverne Dalmacije. Godinama kasnije, 1950., braneći istom logikom Zimsko ljetovanje, pisao je kao da je i dalje bio urednik Magazina: „Krstarili su tuda i drugi predstavnici kulture - od trijangulacionih i agronomskih ekipa i malarioloških anketnih komisija do geografa, arheografa, etnografa, filologa, popova i fratara manijaka historije ili manijaka jezika, te uopće sakupljači i popisivači narodnog blaga svake ruke. I oni su popisali svaki kamen, prepisali svaki natpis, precrtali svaku šaru veziva, zabilježili svaku jezičnu apartnost - ali skoro niko nije obratio ozbiljniju pažnju na živog čovjeka i na njegova životna pitanja. Možda i zato što se forme života tog kraja i njihova puna strahota ne otkrivaju oku letimičnog prolaznika ili površnog promatrača, koji vidi „narod“ kroz sheme i apstrakcije, već jedino oku čovjeka, koji nije izgubio konkretni dodir s rodnom zemljom i živim ljudima u njoj.“ ${ }^{“ 2}$

Budući da je Desnica višekratno isticao uvjerenje da „nezamjenljiva vrijednost književnosti, koja određuje njenu funkciju i njeno mjesto u sferi duha, leži u tome što nam otkriva o čovjeku istine onog reda koje nam ni historija, ni sociologija, ni naučna psihologija, ni ma koja druga duhovna djelatnost ne mogu da pruže“, ono nikada nije moglo biti utemeljeno na, kako je sâm formulirao, „ahistoričkom pasatizmu“. ${ }^{3}$ Ipak je otvoreno pitanje što je 1930-ih godina podrazumijevao pod pojmovima „povijest“, „prošlost“, „(h)istorija“ $i$,(h) istoriografija“. O tome postoji, koliko nam je poznato, svega jedan eksplicitni iskaz polemičke naravi, a nastao je u prepisci s Privredno-kulturnom maticom Sjeverne Dalmacije u vezi s koncepcijom $M S D$-a: „Jasno je što može da dodje pod rubriku 'KNJIŽEVNOST' pa tu nema prigovora. Pod rubriku 'NAŠI PROBLEMI' mogu da se svrstaju napisi najrazličitijeg sadržaja, pa i to može da se prihvati. Nije tako s rubrikom 'ISTORIJA'. Ta riječ je stručni izraz koji označuje jednu nauku. Prema tome, u tu rubriku idu samo napisi o važnijim, općenitijim dogadjajima, i ličnostima, pokretima. Nije 'istorija' sve ono što je prošlost. Iz članaka Miloša Parente, Boška Desnice, Ljubomira Vlačića čitalac bi dobio dojam da je tu u naslovu riječ 'Istorija' upotrebljena zbilja u stručnom smislu, kao nauka, istoriografija, pa bi se začudio kad bi vidio u istom odjeljku napise koji ne spadaju u istoriju u tom smislu. Nekrološčići o Josi Mihaljeviću, Danici Baljak, Jelisaveti Simić, uspomene na Artura Evansa itd, ma koliko pretstavljali našu i nama dragu prošlost, nisu 'istorija' u gornjem smislu, pa takovi člančići ne mogu da stoje uz historiografske radnje i monografije. Isto vrijedi i za članke o prof. Grupkoviću, nisu 'istorija' ni zapisi iz naše nedavne polit[ičke] prošlosti, ni članak o našim privrednim i kult[urnim] društvima do oslobodjenja, a najmanje člančić o Sundečićevu boravku u Žegaru. O tome mislim da će se saglasiti svi. Trebalo bi dakle to podijeliti u dvije rubrike: ISTORIJA, i tu bi došli članci o krupnijim istorijskim ličnosti-

\footnotetext{
Magazin Sjeverne Dalmacije (dalje: MSD), sv. I/1934., 3.

2 „Razgovor s piscem o 'Zimskom ljetovanju' (intervju za radio)“, Vladan DesnicA, Hotimično iskustvo: diskurzivna proza Vladana Desnice. Knjiga druga (prir. Dušan Marinković), Zagreb 2006., 144-145.

3 „Doprinijeti vječitom cilju: očovječenju čovjeka“, isto, 95.
} 
ma, koje su čak postale junaci narodne epike, o seobama, bunama, dakle o dogadjajima, pokretima i ličnostima koje pripadaju istoriji; druga rubrika može da nosi naslov 'IZ NEDAVNE PROŠLOSTI' ili, još bolje, 'NAŠI LJUDI I USTANOVE', ili kako se već nadje za zgodno." ${ }^{\text {. }}$

Kada je riječ o „konkretn(om) dodir(u) s rodnom zemljom i živim ljudima u njoj“, Desnica je načelno bio na razini suvremenih epistemoloških i teorijskih promjena u znanostima o čovjeku, koje su u štočemu aktualne i danas. Gotovo svaki mikrohistoričar, na primjer, prihvatit će - slijedeći Desničinu logiku „konkretnog dodira“ - njegovo mišljenje da je realistično „ne samo ono što faktično postoji i živi u historijskoj stvarnosti, ili ono što odgovara zakonima 'možebitnosti' koje je otkrila [zna - nap. V. D.] nauka, već i sve ono što faktično, odistinski prođe čovjeku kroz glavu i kroz osjećaje, sve ono što promislimo, što želimo, što dočaravamo, što sanjamo ". 5 Međutim, kada je riječ o spomenutom navodu iz 1933. godine, njegovo definiranje historiografske problematike Sjeverne Dalmacije na razini članaka „o krupnijim istorijskim ličnostima, koje su čak postale junaci narodne epike, o seobama, bunama, dakle o dogadjajima, pokretima i ličnostima koje pripadaju istoriji; (...)“ svjedočanstvo je shvaćanju koje je bliže historiografskom tradicionalizmu nego modernizmu. ${ }^{6}$ Rekli bismo da je njegovo shvaćanje historijskih istina u to doba bilo ambivalentno.

Ovaj članak nastaje iz potrebe za propitivanjem koliko i kako se Vladan Desnica - odbijajući „sheme i apstrakcije“ o ljudima dalmatinskog sjevera, o ljudima općenito - i nakon $M S D$-a posvećivao historijskim, dakle znanstvenim istinama o predjelima koje će 1950. godine književno otkriti u Zimskom ljetovanju na način koji je i danas aktualan, kao što je bio u vrijeme nastanka. $S$ tim u vezi, rad se fokusira na Vladana Desnicu kao aktera u nastanku Istorije kotarskih uskoka njegova strica Boška Desnice, koji je, pored oca Uroša, inače, imao najvećeg utjecaja na Vladanovo ljudsko sazrijevanje. ${ }^{7}$

Pritom se polazi od pretpostavke, koju sam istraživački već provjeravao, da je Vladan Desnica, radikalizirajući svoja traganja za umjetničkim istinama nakon 1935./1936. godine, produbio svoj interes i za historijske istine. ${ }^{8}$ Neupitno je da je u navedenom razdoblju izgubio interes za praktične regionalističke kulturološke i historiografske implikacije uredničke koncepcije časopisa. Bio je to ipak situacijski, politički iznuđen izbor jer mu je $M S D$ omogućavao istovremeno propitivanje umjetničkih, historijskih, etnografskih, pri-

4 Osobna ostavština Vladana Desnice (dalje: OOVD), kut. Prepiska do 1945., Vladan Desnica - Privredno-kulturnoj matici Sjeverne Dalmacije, Split, 7. listopada 1933.

5 „O realizmu“, V. Desnica, Hotimično iskustvo: diskurzivna proza Vladana Desnice. Knjiga prva (prir. Dušan Marinković), Zagreb 2006., 195.

6 Pritom, ipak, ne treba gubiti iz vida da je riječ o ulomku pisma čelništvu Prosvjetno-kulturne matice Sjeverne Dalmacije, koje su činili ljudi koji sigurno nisu bili zastupnici historiografskih inovacija. Imajući na umu što je sve objavio u MSD-u 1934. i 1935. godine, moguće je zaključiti da je kao urednik bio mnogo bliži načelima iz nenaslovljenog predgovora $M S D$-a 1934. nego citiranim formulacijama iz pisma Matici.

7 Boško Desnica, Istorija kotarskih uskoka, sv. I: 1646-1684, Beograd 1950. /ćir./; sv. II: 1684 - 1749 , Beograd 1951. /ćir./; Isti, Sabrana djela (priredio i uvodni tekst napisao Milorad Savić), Zagreb 2008., 8-34; Drago RoKsandić, „Vladan Desnica i Magazin Sjeverne Dalmacije: književnik i (ne)moć tradicije“, Vladan Desnica i Split 1920. - 1945. Zbornik radova sa znanstvenog skupa Desničini susreti 2014. (ur. Drago Roksandić i Ivana Cvijović Javorina), Zagreb 2015., 181-234.

Da bi izbjegao često navođenje prezimena Desnica, u nastavku članka autor će se referirati na osobna imena Boško i Vladan. 
rodoznanstvenih i drugih režima čovjekovih istina o sebi, drugima, prirodi, svijetu itd. Sjevernodalmatinsko je obzorje izvorno, ranih 1930-ih godina, smatrao prednošću svoga časopisnog projekta. Priroda i Kultura unutar tih granica očitovale su se - u dugotrajnim, a kontradiktornim kontinentalnim, litoralnim i inzularnim antropizacijskim dinamikama - u načinima koji su u regionalno osmišljenim studijama ponajprije i mogli doći do svoga punog izražaja. Njegovi umjetnički eseji o Dositeju Obradoviću i Mirku Koroliji mogu se čitati i kao historiografski ogledi, a noveliziran Jandrija Kutlača nerazumljiv je izvan dinamike vremenskih cezura historijske provenijencije. Intencionalno, $M S D$ je u Desničinoj vizuri bio mnogo više od "magazina“.

Njegova radikalizirana traganja za umjetničkim istinama nakon 1935./1936. godine, dakle, nisu isključivala inovativne pristupe historijskim, sociološkim, prirodoznanstvenim i drugim istinama. Uostalom, uređivanje $M S D$-a omogućilo mu je izravnu komunikaciju sa znanstvenicima različitih profesionalnih specijalizacija. Sačuvana Desničina korespondencija svjedoči da je kao tridesetogodišnjak bio sposoban steći njihovo povjerenje i u više slučajeva izazvati interes onih koji ga nisu osobno poznavali za susret s njime. Ona je svjedočanstvo i o tome da je tada razvijao živ, pojačan čitateljski interes za inovacije u društveno-humanističkim, pa i prirodoznanstvenim istraživanjima (npr. u sociologiji i antropologiji te socijalnoj medicini). ${ }^{9}$

Stoga je samo prividno paradoksalno da se njegov aktivan interes za arhivistički utemeljenu kritičku historiografiju povećavao nakon 1935. godine. Njegova recepcija kročeanske estetike nije bila ahistorička, a i inače je in patrimonio baštinio živ interes za povijest i historiografska istraživanja. Stric Boško od svoje se mladosti pasionirano bavio arhivskim istraživanjima fokusiranima na ranonovovjekovne Ravne kotare, Bukovicu i Zadar, a u kasnim 1930-im godinama nastojao je finalizirati svoj magnum opus, Istoriju kotarskih uskoka, te objaviti kritičko izdanje Šimuna Ljubavca, zadarskog erudita iz 17. stoljeća. ${ }^{10}$ U Ljubavčevu slučaju bila je riječ o izdanju važnu za razumijevanje nastanka modernog pojma Sjeverne Dalmacije, odnosno današnje zadarske subregije, pa i o svojevrsnom ključu za razumijevanje sjevernodalmatinskoga ranonovovjekovnog opusa Boška Desnice samog. ${ }^{11}$ Vladan je svog strica („barbu“), s kojim je inače bio u redovitoj prepisci na relaciji Split - Obrovac, poticao i pomagao da u ovim svojim istraživanjima uspije. ${ }^{12}$

8 D. Roksandić, „Kud koje žure brzi kraci / a vode svi u bespućé: Vladan Desnica u Splitu od 1935. do 1941. godine“, Split i Vladan Desnica 1918. - 1945.: umjetničko stvaralaštvo izmedu kulture i politike. Zbornik radova sa znanstvenog skupa Desničini susreti 2015. (ur. Drago Roksandić i Ivana Cvijović Javorina), Zagreb 2016., 415-458.

9 Isti, „Vladan Desnica i Magazin Sjeverne Dalmacije“, 181-234.

10 B. Desnica, Sabrana djela, 8-34; D. Roksandić, „Kud koje žure brzi kraci / a vode svi u bespuće“", 424-433; B. DesniCA, „Zadranin Šimun Ljubavac. Jedan dalmatinski erudit XVII vijeka“, Glasnik Primorske banovine, 1/1938., br. $1,173-181$.

11 D. Roksandić, „'Kud koje žure brzi kraci / a vode svi u bespuće'“, 437-445.

12 Njihova je suradnja, kao i ona sa sve bolesnijim ocem, bila mnogo slabija kada je riječ o Vladanovu književnom stvaralaštvu. Nakon 1935. godine, očigledno i pod stričevim utjecajem, odlučio je napustiti svoju namjeru da novelu Životna staza Jandrije Kutlače pretvori u roman, s prepoznatljivim regionalnim konotacijama. Neovisno o stričevim željama da nastavi pisati eseje o književnim stvaraocima koji su bitni za razumijevanje kulturne baštine Sjeverne Dalmacije, takve radove, izgleda, više nije pisao. Čini se da nisu sačuvani tragovi prepiske sa stricem u vezi s radom na (kasnije naslovljenim) Proljećima Ivana Galeba, pa ne bi trebalo isključiti pretpostavku da se nakon Boškove kritike rukopisa Životne staze Jandrije Kutlače s njime više nije savjetovao o projektu svog romana. 


\section{JEDNOG PO JEDNOG PREDATI VATRI SVE ČESTITE SERDARE!}

Djelomično sačuvana prepiska s Boškom (1886. - 1945.) iz 1920-ih i 1930-ih godina - koju najvećim dijelom čine Boškova pisma Vladanu - otkriva s vremenom sve veće Vladanove historiografske interese, historiografsku kulturu mišljenja, pa i historiografske kompetencije. Nigdje to toliko ne dolazi do izražaja koliko u nekoliko sačuvanih pisama upravo iz kasnih 1930-ih godina, kada je Boško, pored ostalog, finalizirao svoja dugogodišnja istraživanja arhivskih vrela za povijest ravnokotarskih uskoka od sredine 17. do sredine 18. stoljeća, htijući ih objaviti u izdanju Srpske kraljevske akademije u Beogradu.

Boško - zadarski đak i bečki pravnik, poliglot, a obrovački odvjetnik - od rane mladosti bio je predan istraživač arhivskoga gradiva o uskočkoj, „morlačkoj Dalmaciji“ ranoga novog vijeka. ${ }^{13}$ Neovisno o tome koliko ga je dodatno mogla motivirati obiteljska tradicija, ključno je bilo njegovo uvjerenje da su tradicionalne zajednice kontinentalne, malarične Dalmacije - koje su stalno bile u pokretu, na rubu gladi i vrlo kratkoga prosječnog životnog vijeka - opstojale kao društvo bez kulture pamćenja dugog trajanja, društvo bez razvijene svijesti o sebi u modernoj povijesti Dalmacije. Arhivski istražujući „dalmatinske Morlake“ kao narod tragične sudbine na imperijalnim razdjelnicama ranoga novog vijeka, ali i kolektivnog aktera povijesnih promjena kojima će najmanje humanizirati vlastiti život, Boško je zarana razvio potrebu za istraživanjem i kritičkim oživljavanjem zaboravljene „morlačke“ prošlosti te da u moru iskustava nasilja i nesreća otkriva njezin humani smisao, koji će moći biti poticajan za budućnost kako samih potomaka ranonovovjekovnih „Morlaka“ tako i ljudi/naroda koji su njihovi baštinici. Boško je recipirao pojam morlačkog etnika, ignorirajući činjenicu da je riječ o mletačkom konstruktu i ne ulazeći u hrvatske i srpske aspekte morlačke baštine ranoga novog vijeka. ${ }^{14}$

Ne prestajući desetljećima prikupljati izvorno povijesno gradivo, objavljivao je mnogobrojne kratke, inteligentne i žurnalistički vrlo čitljive priloge te stekao prestiž i među stručnjacima u historiografiji. Budući da nije bio ni profesionalni arhivist ni profesionalni historiograf, vrijedno je i danas čitati njegove lucidne, bogato izražajne, a jezično dosta nemarno pisane radove o temama kojima se u njegovo vrijeme malo tko ili nitko nije bavio. ${ }^{15}$ Interes je tim više opravdan što je pisao na temelju nekorištenih povijesnih izvora i uvijek sa sviješću da je svaka njegova tema tek uvod u moguće daljnje istraživanje. Svojim je pristupom Boško neizbježno razvijao interese koji su i u njegovu vremenu bili multidisciplinarni, a time i inovativni. Time je i gradivo koje je prikupljao i objavljivao u raznim žanrovima i na različite načine moglo udovoljiti i mikro- i makrohistorijskim istraživačkim

$\overline{13}$ Boško Desnica počeo je istraživati u zadarskim arhivima i knjižnicama već kao đak zadarske talijanske gimnazije na prijelazu 19. u 20. stoljeće na poticaj svoga gimnazijskog profesora, don Luke Jelića: „...sastavljač ovog zbornika duguje uspomeni tog simpatičnog i talentovanog osobenjaka duboku i istinsku zahvalnost, što ga je on, još kao gimnazistu uveo u zadarske arhive i biblioteke i uputio u onaj istraživački rad, koji traži toliko samoodricanja, ali pravi dostupnim intenzivna i uzvišena duševna zadovoljstva." (B. Desnica, Istorija kotarskih uskoka, sv. I, 4. /ćir./)

14 Sličan odnos prema „Morlacima“ imao je i Vladan Desnica u eseju „Mirko Korolija i njegov kraj” (MSD, sv. II/1935., 117-129, napose str. 118).

15 B. Desnica, Sabrana djela, 552 str. /ćir. i lat./ 
potrebama te biti vodič za rekonstrukciju ljudskih drama i, češće, tragedija na imperijalnom višegraničju u dugom povijesnom trajanju.

Obavljenim radovima i stečenom reputacijom sâm je stvorio šansu da kasnih 1930-ih dobije poziv iz Srpske kraljevske akademije za tiskanjem opsežnog kritičkog izbora arhivskog gradiva o „morlačkoj Dalmaciji“ u 17. i 18. stoljeću, s težištem na razdoblju Kandijskog i Morejskog rata. Kada je taj poziv točno stigao, zasad nije poznato. Bit će da su tome pridonijeli njegova višegodišnja komunikacija s Jovanom Tomićem (1869. - 1932.), ali i s drugim beogradskim povjesničarima te neupitna kvalificiranost, kada je riječ o poznavanju gradiva za povijest Dalmacije u ranome novom vijeku: „Ne znam jesam li ti javio da je meni Akademija odgovorila i obećala da će mi poslati Tomićeve ispise u koliko se odnose na ove krajeve da ih obradim, kad Tomićeva zaostavština, koja izgleda nije još ni predana Akad[emiji], bude sregjena. "16 Tri godine kasnije Boško je uvelike za Akademiju pripremao Zbornik. Prema Godišnjaku Srpske kraljevske akademije za 1938. godinu, Vladimir Ćorović je na I. skupu Akademije društvenih nauka, održanom 5. travnja 1938. godine, pod t. 5 referirao o rukopisu Boška Desnice Ispisi iz Zadarskog arhiva o uskocima. Tom je prilikom odlučeno da Ćorović i Jovan Radonić „rad pregledaju“. ${ }^{17}$ Dakle, Akademija je donijela odluku o otvaranju postupka o rukopisu koji nije bio kompletiran, a očito ni sređen na način koji bi zadovoljio kriterije samog Boška Desnice: „Zbornik vrlo polako odmiče i proći će dosta vremena dok bude gotov. Do sad sam poslao Ćoroviću oko 200 dokumenata. Na drugu mi pošiljku nije uopće odgovorio. Ja sam na muci sa prepisivanjem: pisar mi ne zna talijanski i griješi grozno a ja sam ne stižem, a i u koliko stignem, tipkanje me silno zamara. Mislio sam ovo desetak bezraspravnih dana otići u Karin, ponijeti mašinu e darghe dentro, ali eto Brace pozvao neku svoju škamtariju, pa moradoh ostati! I tako stvar sporo odmiče, a žao mi je jer što izbliže gledam one dokumente, to su sve više zaljubljujem u njih. " ${ }^{18}$ Boškov rad na ovoj zbirci izvora napredovao je neovisno o tome što je moglo proizaći iz procedure u Akademiji s njime u vezi. Tim je više Boško bio zatečen kada je obaviješten o zaključcima. Na III. skupu Akademije društvenih nauka, održanom u Akademiji 30. lipnja 1938. godine, zapisnički je konstatirano:

3. Pročitan je referat g.g. Vl[adimira] Ćorovića i Jov[ana] Radonića o radu g. Boška Desnice „Ispisi iz Zadarskog arhiva o uskocima“. Odlučeno je da se rad vrati piscu da postupi po napomenama g.g. referenata. ${ }^{19}$

16 Prema M. Saviću, Boško Desnica i Jovan Tomić korespondirali su od 1908. do 1929. godine, tj. do Tomićeve smrti. V. B. Desnica, Sabrana djela, 12. lćir./; OOVD, kut. Prepiska do 1945., Boško Desnica - Vladanu Desnici, Obrovac, 25. ožujka 1935.

17 Godišnjak XLVIII 1938, Srpska kraljevska akademija, Beograd 1939. /ćir./ Srdačno zahvaljujem kolegi Veljku Staniću iz Balkanološkog instituta SANU, koji je na moju molbu u Arhivu i Biblioteci SANU prikupio sve raspoložive obavijesti o pripremi za objavljivanje Desničine Istorije kotarskih uskoka u SANU.

18 Boško Desnica - Vladanu Desnici, [Obrovac], [nakon] 17. travnja 1938. U uskršnjem broju Novog doba, 17. travnja 1938., Boško Desnica objavio je članak „Pisma Kotoranina Antuna Bizanti isusovcu o. Filipu Riceputi“. U spomenutom pismu zahvalio je Vladanu na brizi za ovaj članak: „Fala ti na korekturi. Ovo je prvi put da mi N[ovo] D[oba] štampa nešto bez grješaka."

19 Godišnjak XLVIII 1938. Ovaj referat, kao i nijedan drugi u vezi s Ispisima Boška Desnice, nije sačuvan u Arhivu Srpske akademije nauka i umetnosti ili, pak, nije dostupan, pa su sačuvana pisma iz prepiske između Boška i Vladana Desnice rijetki tragovi rada na ovom uistinu respektabilnom projektu. 
O kakvim je „napomenama“ bila riječ, a još više o njihovu učinku na Boška, moguće je u osnovi shvatiti iz Boškova pisma Vladanu od 13. srpnja 1938. godine: „A sad na Zbornik. Šaljem ti ovgje i dokumente koje mi je akademija povratila i one, koje sam ja u megjuvremenu bio spremio da joj pošaljem. Od ovih potonjih nekoliko komada je još u kopjaturi pa ću ti njih naknadno poslati. Pisao sam još večeras Akad[emiji] i zatražio ona pravila za izdanja tal[ijanskih] tekstova na koja se poziva Radonićev referat. ${ }^{20} \mathrm{Kad}$ mi dogju poslaću ti i njih. Megjutim ti počni polako pregledavati zbirku i popravljati ortografiju talijanskog lektora prema napomenama Radonića, a 'srbizirati' srpski tekst prema želji Ćorovića. Osim toga mogao bi sastaviti i predgovor, a jer bi izradio onaj dio tog predgovora, koji se odnosi na gragju i arhive. Dajem ti sav ovaj posao i ovu zanovet jer si se sam više puta ponudio, dakle, ako te stiglo ovo zlo krivi sebe. “21 Dakle, Zbornik je odjedanput postao „zlo“!

Iako su prema citiranom zapisniku akademici Ćorović i Radonić podnijeli Akademiji zajednički izvještaj o Desničinu rukopisu, iz Boškovog je pisma jasno da su oni pojedinačno iznijeli vlastite „napomene“. Težište Radonićevih bilo je na ortografiji prijepisa talijanskih izvornika, a Ćorovićevih na „srbiziranju“ Boškova jezika. Obje je „napomene“ teško prihvatio. Tada je već imao tridesetak godina iskustva u radu s arhivskim vrelima, ali i izdanjima vrela mletačke provenijencije. Bio je zaratinski govornik mletačkog dijalekta i odličan poznavalac modernoga talijanskog jezika. Arhivistički i historiografski sazrijevao je između Zadra, Venecije, Beča, Zagreba i Beograda. Kao autodidakt, razvio je tehnike i metode kritičkoga korištenja izvorima, usklađivane s potrebama istraživanja problema koji su ga osobno motivirali. Akademijin poziv bio mu je velika zadovoljština, ali mu je životno stigao prekasno da bi smogao volju i snagu za prerađivanjem prikupljenog materijala prema „napomenama“, koje mu se očito nisu činile dovoljno utemeljenima.

Morala ga je povrijediti i Ćorovićeva „napomena“ u vezi sa „srbiziranjem“ jezika. Govorio je sjevernodalmatinskim srpskim, tj. urbanom novoštokavskom ijekavštinom, otvorenom prema regionalnim kroatizmima $i$, nadasve, romanizmima (zaratinizmima, venecijanizmima i talijanizmima). Boško je svoje autohtono i autentično srpstvo stvarao i potvrđivao upravo takvim svojim jezikom i uopće se nije trudio prilagođavati ga imperativima „beogradskog stila“. Njegov je problem načelno bio problem unutarsrpskog, intranacionalnog interkulturalizma. Ipak je bio svjestan da će jezik njegova predgovora, regeste, bilješke, dakle metatekstovi u zbirci izbora morati biti standardizirani, prilagođeni uzusima Akademije. Stoga mu nije ostalo ništa drugo nego zatražiti Vladanovu pomoć, pouzdajući se u njegovo poznavanje vrela, problema, jezikâ i, nadasve, u njegovu radnu disciplinu. Očigledno ga nije trebao uvjeravati jer je Vladan sâm bio spreman posvetiti se svim spomenutim poslovima.

Imajući na umu što je Jorjo Tadić, hrvatski povjesničar, profesor na Univerzitetu u Beogradu, iskusan istraživač zamjerne međunarodne reputacije, postulirao u spomenutom djelu kao pravila za kritička izdanja srednjovjekovnih latinski i talijanski pisanih izvora, Boško

20 Jorjo Tadić, Pisma i uputstva Dubrovačke Republike, knj. I., Beograd 1935. /ćir./ V. „Predgovor“, I.-XIII.

21 OOVD, kut. Prepiska do 1945., Boško Desnica - Vladanu Desnica, Obrovac, 13. srpnja 1938. 
je doista morao očajavati. Tadićeve su upute u vrijeme objavljivanja na svjetskoj razini, a uvelike su i danas referentne:

Pri ispisivanju i objavljivanju dokumenata držali smo se sledećih pravila:

I Smatrajući da svaki dokument treba objaviti što razumljivije, jasnije i za današnje shvaćanje što pristupačnije, pazili smo na sledeće:

1 Sve kratice smo sasvim razrešili, a pri tome nismo nikakvim znakovima (zagradama, kursivnim slovima ili sličnim) označili što je u takvim rečima umetnuto. U nekim slučajevima, kada nam pojedine reči nisu bile jasne, doneli smo u zagradama naše tumačenje kratice sa znakom pitanja (?).

2 Velika i mala slova pisali smo prema pravilima koja danas važe za talijanski jezik, a u latinskom jeziku upravljali smo se po zakonima latinske gramatike (na pr. geografske prideve uvek smo pisali velikim slovima).

3 Interpunkciju smo upotrebili modernu, logičnu, za talijanski jezik, a za latinski smo još uzeli u obzir i dosad upotrebljavanu gramatičnu.

$(\ldots)^{22}$

Šesnaest njegovih pravila, obrazloženih na trima knjižnim stranama, doista su mogle biti razlogom da Boško odustane od objavljivanja svojih ispisa u Srpskoj kraljevskoj akademiji. Njegova je zbirka bila tematska, fokusirana na kotarske uskoke („Morlake“) u 17. i 18. stoljeću, a Tadićeva je logika bila institucionalna, državna. Tadić je objavljivao serijalno umrežene dokumente, a Desnica izabrano gradivo različitih provenijencija i umrežavao ga duž kronološke matrice. Tadićeve upute uopće nisu bile „opće“ - kako je to ustvrdio Boško, insinuirajući mu srebroljublje („popio paru Radoniću“) - nego primjerene potrebama rada na dugoročno projiciranom projektu objavljivanja gradiva pohranjenog u Dubrovačkom arhivu od 1358. do 1808. godine. Stoga je Boško razdraženo reagirao: „One famozne 'upute za publikaciju dokumenata na italijanskom' nisu nikakve opće upute, već subjektivni nazori Jorja Tadića, koji je popio paru Radoniću. Na moj zahtjev, akademija mi je poslala Tadićev zbornik, koji u uvodu tretira to pitanje. Šaljem ti ga da ga pročitaš. Ako bi ti ćeo da istaknute nazore pobiješ, ja bi tvoje argumente unio u predgovor, jer niti mislim niti znam kako da 'saobrazim' zbornik nazorima referenata i stvar me tako nervira, da nisam daleko od odluke de mandar li tutti tamo kud Srbijanci šalju, i propri [...] pa da odustanem od namjeravane publikacije. Žao mi je samo uloženog truda i izgubljenog vremena, a neugodno mi je i što se za ovu stvar rasčulo po Judeji, pa bi Matičari mogli misliti da me Akademija odbila. Nego nervoza će u jednom času nadjačati i ta žaljenja, pa ću onda lijepo ove zime sjesti kod štuve i jednog po jednog predati vatri sve čestite serdare!“ ${ }^{23} \mathrm{Da}$ nije bilo straha od povrijeđene sujete, od zajedljivih reakcija lokalnih neprijatelja („Judeja“, „Matičari“), bio bi spreman odustati od Zbornika, a moćnike u Akademiji poslati u rodna mjesta!24 Vladan, imajući na umu s koliko je zanosa i napora Boško godinama prikupljao gradivo i kakve je sve teškoće imao pri osiguravanju vjerodostojnih prijepisa dokumenata u Zadru nakon što su Desnice napustile Zadar 1920. godine, pa i u Veneciji, potrudio se

22 J. TAdić, Pisma i uputstva Dubrovačke Republike. V. „Predgovor“, XI.

23 OOVD, kut. Prepiska do 1945., Boško Desnica - Vladanu Desnici, Obrovac, 29. srpnja 1938.

24 „Matičari“, ljudi iz kruga Privredno-prosvjetne matice za Sjevernu Dalmaciju. 
učiniti sve što je bilo potrebno i moguće kako bi se Boškovi ispisi prihvatili za objavljivanje u obliku koji je u osnovi smatrao prihvatljivim: „...jedini [je] ispravan kriterijum taj, da dokumente za ovaj Zbornik donesem tačno onako kako stoje u originalu, bez ikakvih bilo gramatičkih bilo ortografskih ispravaka ili izmena. ${ }^{\text {"25 }}$ Bila bi nevjerojatna pretpostavka da je Vladan podržavao Boška u naumu da polemizira s Tadićem, Radonićem i Ćorovićem. Pomogao mu je formulirati argumente u prilog rješenja koje je upravo citirano. Imajući na umu različite provenijencije prikupljenih dokumenata, razine pismenosti, raznolikosti obrazaca itd., ujednačavanje kriterija kritičkog objavljivanja bilo je moguće, ali i mnogo zahtjevnije nego u Tadićevu dubrovačkom slučaju. Svjestan, s druge strane, činjenice da je neke dokumente Boško sâm prepisivao, a da su mnoge druge prepisivali različiti prepisivači u dužem vremenskom trajanju i da je dvojbeno jesu li prijepisi uvijek bili kolacionirani $s$ izvornicima te uzimajući u obzir da su prijepisi mahom bili rukopisni, a da ih je Akademiji trebalo predati u strojopisu, Vladan se uključio u velik posao koji je trebalo obaviti kako bi se rukopis sredio na održiv način, ne ignorirajući Akademijine intencije. Uspio je pronaći formule koje su bile prihvatljive i Akademiji i Bošku. ${ }^{26}$ Sudeći prema intonaciji Boškova kolovoškog pisma, Vladan je svojim doprinosima uspio ne samo smiriti uzrujanog Boška nego i potaknuti u njemu novi radni polet: „Velika ti hvala na elaboratu, koji je odličan. ${ }^{27}$ Onaj prvi dio (karakter, svrha i značenje dokumenata - jezik) rimpašta i povezao sa onim što mu prethodi, a drugi ću (načela kod publikacije) koredati primjerima kad se, ove druge negjelje, vratim u Obrovac, jer sam, ne misleći da će mi trebati, poslao tamo zbornik. Neznam bili u zbornik interpola i onaj štatut objavljen u Magazinu 35. Bio bi vrlo na mjestu (kao i dokumenti o ligama) ali se bojim zamjerke da je to već objavljena gragja. Šta misliš ti? “28

Kakva promjena Boškova raspoloženja u nepunih mjesec dana! Ništa manje nije važno ni to što mu je predložio formulacije u Predgovoru koje su autorski personalizirale Boškov rad, kako u koncepcijskom tako i u genetičkom smislu, dajući ključ za razumijevanje njegovih istraživačkih dosega. Nekoliko dana kasnije, Boško je prihvatio i neke Vladanove sugestije historiografske naravi: „Jutros, činio sam saldo, sravnio sam Praginu bilješku sa inventarom i napisao umetak, koji ti prilažem. Fala ti što si me na ovo upozorio, jer meni ova Pragina radnja nije bila poznata. ${ }^{29}$ U Karinu sam dovršio i onaj dio predgovora koji se odnosi na opis zadarskog arhiva. Još mi fali da popunim onaj svoj dio, i da, prema tvom savjetu, nadodam štatute i dokumente o ligama pa ću biti gotov i sa zbornikom. Kad ću to moći da dovršim - neznam jer me ovgje čeka jedan pakleni posao. Nemam vremena da duljim. Fala ti mnogo na svemu. “30 Što je sve značilo „fala ti mnogo na svemu“, vjerojat-

25 „Predgovor“, u: B. DesnicA, Istorija kotarskih uskoka, sv. I, 10. /ćir./

26 Sačuvano je Vladanovo pismo Bošku iz Splita, 5. kolovoza 1938., kojim potvrđuje da je primio Tadićevu knjigu i obećava poslati mu koncept onog dijela predgovora koji je u vezi s gramatičkim i ortografskim „saobražavanjem“ tekstova. Leksem „saobražavanje“ stavljali su pod navodne znakove i Boško i Vladan. V. B. Desnica, Sabrana djela, 21. /ćir./

27 „(Z)a predgovor Zborniku“, dopisano iznad teksta drugim rukopisom i vezano za „elaboratu“.

28 Boško Desnica - Vladanu Desnici, Karin, 24. kolovoza 1938.

29 Giuseppe Praga vrlo je mnogo pisao, pored ostalog, o arhivskim i literarnim izvorima za povijest Dalmacije. V. Giuseppe Praga, Scritti sulla Dalmazia (a cura di Egidio Ivetic), tomo I-III, Rovigno 2014.

30 OOVD, kut. Prepiska do 1945., Boško Desnica - Vladanu Desnici, Obrovac, 28. kolovoza 1938. 
no nikada neće biti moguće saznati, iako ni to „svemu“ nije bilo sve što je trebalo. Uskoro je nastao novi zastoj u komunikaciji između Vladana i Boška, koji je ponovno pokvario raspoloženje, pa i odnos prema izdanju. Vladana je sustizalo sve više poslova i, očigledno, nije stizao pratiti sve nestrpljivijeg strica: „Očekivao sam da mi povratiš definitivno korigovani predgovor i da mi javiš tvoje mišljenje o utisku, koji ti pravi kao cjelina - megjutim o tome ni mukaet. Ja sam popunio zbornik dokumentima o ligama, Ćivranovim izvještajem i još nekim sitnijim, tako da je sad mnogo bogatiji i raznovrsniji. Pregledao sam gotovo polovicu dokumenata i ispravio greške izmakle mi kod prvog pregleda. Dok mi stigne tvoj imprimatur za predgovor, pregledaću i ovo što ostaje i varati (sic!) ga, pa nek ide za svojom zvijezdom. Više mi je krv moju popio!" 31 Pismo je prvorazredno svjedočanstvo da je Vladan u konačnici korigirao cijeli Predgovor. Svi su nužni poslovi ipak obavljeni jer je Akademija društvenih nauka na V. skupu, održanom 5. prosinca 1938. godine, donijela sljedeći zaključak:

Pročitani su naknadni referati g.g. Jov[ana] Radonića i Vl[adimira] Ćorovića o radu g. Boška Desnice „Ispisi iz Zadarskog arhiva o uskocima 1646-1684“. Odlučeno je da se rad primi i objavi u Zborniku za istoriju, jezik i književnost drugog odeljenja. ${ }^{32}$

Uočljivo je da je naslov donekle promijenjen: Ispisi iz Zadarskog arhiva o uskocima 1646-1684. Neobično je to što je previđena činjenica da su uvršteni ispisi potjecali iz različitih zadarskih arhiva i knjižnica, i to ne samo iz zadarskih! Na kraju, „Zadarski arhiv“ kao ustanova takva naziva nikada nije ni postojao.

Boško Desnica nije doživio objavljivanje svog Zbornika. Umro je 1. travnja 1945. godine kao prvi hrvatski/jugoslavenski ravnatelj Državnog arhiva u Zadru. Bio je to dovoljno respektabilan razlog da se Srpsku akademiju nauka podsjeti na odluku iz 1938. godine, ali je tada to podrazumijevalo revizijski postupak:

Skupovi odeljenja društvenih nauka SAN

III Skup, 29 juna 1948 god.

3. - pitanje revizije rukopisa primljenih za Akademijina izdanja pre okupacije i za vreme okupacije. - Skup donosi odluku da akademici i dopisnici, čiji su radovi primljeni u to vreme za Akademijina izdanja, pregledaju sami svoje radove i podnesu izveštaj o tome da li se mogu štampati. Za radove pisaca izvan Akademije Skup donosi odluku da se obrazuje redakcioni odbor u koji bira: akademika G. Ostrogorskog, akademika D. Nedeljkovića, dopisnika Vojislava Radovanovića i dopisnika V[iktora] Novaka, i da stručni članovi toga odbora pregledaju radove i podnesu Odeljenju referate da li se sada mogu štampati ili ne. ${ }^{33}$

Revizija je kratko trajala i već 24 . rujna 1948. godine IV. skup Odeljenja društvenih nauka Srpske akademije nauka donio je sljedeću odluku:

\footnotetext{
31 OOVD, kut. Prepiska do 1945., Boško Desnica - Vladanu Desnici, Obrovac, konac 1938. Pismo vjerojatno potječe iz studenog 1938. godine.

32 Godišnjak XLVIII 1938, /ćir./.

33 Godišnjak LV 1948, Srpska akademija nauka, Beograd 1951., 223-224. /ćir./
} 
12. - Referat akademika G. Ostrogorskog i dopisnika V. Novaka o radu Boška Desnice „Ispisi iz Zadarskog arhiva o uskocima 1646-1684“ $\mathrm{i}$ „Građa za istoriju kotarskih uskoka 16841742“. - Skup odlučuje da se rad štampa u Zborniku za istoriju, jezik i književnost srpskog naroda, treće odljenje. Za redaktora se određuje akademik J. Radonić, urednik Zbornika trećeg odeljenja. Ispravke u rukopisu će izvršiti Svetozar Brkić, asistent Filozofskog fakulteta u sporazumu sa akademikom J. Radonićem i dopisnikom V. Novakom. ${ }^{34}$

Iznenađuje da je revizijski postupak obuhvatio dvije knjige arhivskoga gradiva, iako je 1938. godine donesena odluka o tiskanju knjige pod prvim navedenim naslovom. Premda je prvospomenuti rukopis bio bezuvjetno prihvaćen, Jovan Radonić, urednik, ali i redaktor izdanja, ovlašten je u suradnji s asistentom Svetozarom Brkićem unijeti „ispravke“ u rukopis! Kakvi su sve „ispravci“ uneseni u ova dva rukopisa, zasad je nemoguće reći. Knjige su objavljene 1951. i 1952. godine, ali je nalog za isplatu honorara u iznosu od 40.000 dinara - što je tada bio uistinu velik iznos - naslovljen na asistenta Svetozara Brkića, kao „punomoćnika naslednika pok. B. Desnice“. Bila je to odluka XIX. skupa Predsedništva Izvršnog odbora Srpske akademije nauka, koji je održan 4. srpnja 1950. godine:

2. - Pitanje honorara za rad pok. Boška Desnice „Ispisi o uskocima iz Zadarskog arhiva“. Odbor odlučuje da se Svetozaru Brkiću, asistentu Univerziteta i punomoćniku naslednika pok. B. Desnice isplati akonto honorara Din. 40.000 pošto nov Pravilnik o nagrađivanju radova štampanih u izdanjima SAN još nije potvrđen i da se o tome izvesti Naučna knjiga. ${ }^{35}$

Zbornik Boška Desnice objavljen je na kraju u dvama svescima pod naslovom Istorija kotarskih uskoka! Nakon Ispisa i Grade završili su pretenciozno kao Istorija! To nikakve veze nije moglo imati s Vladanom, a nemoguće je pretpostaviti da je Jovan Radonić bio ikako povezan s time. Naime, u impresumu izdanja Radonić uopće nije potpisan! Boško Desnica je na koricama unaprijeđen u doktora znanosti, a u prednjem impresumu stoji da je djelo „redigovao Sveozar Brkić asistent Univerziteta“. U kratkom vremenu koje smo imali na raspolaganju nismo mogli utvrditi tko je bio Svetozar Brkić. Nikome takva imena nema traga u srpskoj historiografiji. ${ }^{36}$

Nedoumice u vezi s mogućim promjenama u tekstu Predgovora, koje su nastale nakon 1948. godine, neovisno o tome što je potpisan u Obrovcu, rujna 1938. godine, minimaliziraju mogućnosti intertekstualnih analiza kojima bi se istražio Vladanov udio u Boškovu tekstu. Apoteoza urbaniteta mletačkog Zadra na str. 3. Predgovora neodoljivo podsjeća na argumente kojima se Vladan koristio braneći Zimsko ljetovanje od optužbi 1950. i kasnijih godina. Najupečatljivija je eksplikacija intencija koje su Boška orijentirale u prikupljanju i izboru gradiva za Zbornik na str. 6.: „,...) Dokument je za mene bio važan ne po značajnosti kontingentnog fakta na koji se odnosio već po svetlosti koju je on bacao na pojedine manifestacije ili na čitav kompleks življenja ovog kraja i ljudi u njemu. Nastojao sam stoga da pribeležim sve što je moglo da da sliku ekonomske strukture, socijalnih, verskih, kulturnih prilika, jednom reči, da da atmosferu u kojoj su živeli Morlaci u tom kraju u drugoj polo-

\footnotetext{
Isto, 226. /ćir./

35 Godišnjak LVII 1950, Srpska akademija nauka, Beograd 1951., 118. /ćir./

36 V. Sima Ćırković i Rade Mihaldžıć, Enciklopedija srpske istoriografije, Beograd 1997.
} 
vini XVII veka. Uveren sam da su pribeležene vesti, ma koliko šture i na oko beznačajne, kadre da nas upoznaju sa čitavim stanjem tog naroda, njegovim mentalitetom, životnim

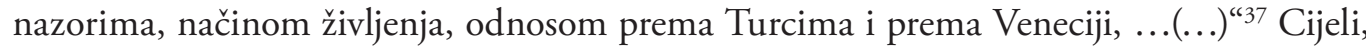
opsežan odlomak programatske je naravi i može ga se tumačiti samo kao plaidoyer za neku buduću historiografiju. Naglasci podjećaju na nenaslovljen predgovor Vladana Desnice u Magazinu Sjeverne Dalmacije 1934. Time se vraćamo na početno, Vladanu toliko važno, problematiziranje odnosa između umjetničkih i historijskih istina o čovjeku. Kako god ih definirali, zajednička im je „istina o čovjeku“.

Prva knjiga Zbornika Boška Desnice ima 360 stranica, a druga 472. Prva sadržava 399, a druga 392 dokumenta. Prvi je dokument iz 1646., a zadnji iz 1749. godine. ${ }^{38}$ Međutim, „Morlaci“, odnosno „Vlaji“ i danas su jedna od najvećih nepoznanica u hrvatskoj i srpskoj, bosanskohercegovačkoj i crnogorskoj povijesti, ali i uvid u svojevrstan usud u mentalitetima ljudi u društvima kontinuiranih modernizacijskih diskontinuiteta. Kakve su šanse interkulturalizma u situaciji kada su „Vlaji“ uvijek oni „Drugi“, neovisno o njihovoj današnjoj narodnosti?

\section{UMJESTO ZAKLJUČKA}

Kao što je Vladan Desnica kasnih 1930-ih, posvećujući se traganju za umjetničkim, književnim istinama o ljudima, držao da ne gubi baveći se problemima historijskih istina o ljudima, tako je i njegov stric i predan sugovornik Boško Desnica, posvećujući se godinama traganju za historijskim istinama, dobivao baveći se i umjetničkim, književnim istinama. Magazin Sjeverne Dalmacije bio je vrhunac njihovih sinergijski usmjerenih aktivnosti u prvoj polovini 1930-ih godina, a rad na pripremi kritičkog izdanja vrela Boška Desnice za povijest kotarskih uskoka u izdanju Srpske kraljevske akademije bio je vrhunac njihove sinergijski usmjerene aktivnosti u drugoj polovini 1930-ih godina. MSD je bio obustavljen nakon drugog godišta, a Istorija kotarskih uskoka objavljena je posmrtno u Srpskoj akademiji nauka šest, odnosno sedam godina nakon Boškove smrti, u redakturi na koju iz različitih razloga ni Vladan nije mogao imati utjecaja. Postavlja se pitanje: a gdje je tu srpsko-hrvatski/hrvatsko-srpski inmterkulturalizam? Izgleda da je ključ u problematizaciji intranacionalnog kulturalizma bez kojeg je onaj internacionalni, u ovom slučaju srpsko-hrvatski/ hrvatsko-srpski, tek korak dalje iz jednih vrtloženja prema drugima i obrnuto.

\footnotetext{
37 B. Desnica, Istorija kotarskih uskoka, sv. I, 6. /ćir./

38 Nedavno je objavljena monografija Tee Mayhew Dalmatia between Ottoman and Venetian Rule. Contado di Zara 1645 - 1718 (Roma 2008). Boško Desnica jedan je od nekolicine najčešće citiranih autora.
} 


\section{$\cos$}

\section{Vladan Desnica and Boško Desnica’s ISTORIJA KOTARSKIH USKOKA}

Desnica's views of history and historiography have mostly been studied within his aesthetic views and, above all, his literary work, and rightfully so. However, his correspondence with his uncle Boško dating from the 1920s and 1930s - comprised mostly of Boško's letters to Vladan - provide an indirect insight into the writer's genuine interest in historiography, a historiographer's way of thinking, and even historiographic competences. Nowhere is this more evident than in the letters from the late 1930s. It was then that Boško Desnica, among other things, finalized his research of the archival sources about the Uskoks of Ravni Kotari between the mid- $17^{\text {th }}$ to the mid- $18^{\text {th }}$ century, which he had conducted for twenty years,with the intention of having it published by the Serbian Royal Academy in Belgrade. Here, Vladan served as the manuscript's most attentive reader, as well as its most erudite critic and, according to the correspondence, the co-author of its Foreword. Anyone familiar with Boško and Vladan's respective writing styles could confirm that after an analysis of the composite qualities of the Foreword. However, only an intertextual analysis of Vladan's works published in Magazin Sjeverne Dalmacije, the polemics related to Zimsko ljetovanje (Summer Vacations in Winter) and the essayistic variations from the 1950s and the 1960s makes it possible to reconstruct Vladan's interventions and formulations in the Foreword to Istorija kotarskih uskoka (The History of the Uskoks of Ravni Kotari), which was posthumously published by the Serbian Academy of Sciences in 1950 and 1951(vol. 1: 1646 - 1684 and vol. 2: 1684 - 1749). This might call for a redefinition of Vladan's views of history and historiography. Also, given that Boško died in 1945, it raises the question of the role Vladan may have played in further negotiations with the Academy, which ended with the manuscript being accepted at the $6^{\text {th }}$ Congress of the Department of Social Sciences of the Serbian Academy of Sciences on the $24^{\text {th }}$ of September 1948, and subsequently published in 1950 and 1951. Vladan's descendants maintain that, while serving as the head of the Legal service of the Ministry of Finance of the People's Republic of Croatia, Vladan did everything he could to gain the necessary support for the publication of Istorija kotarskih uskoka. The shape the manuscript was in when Boško Desnica originally submitted it to the Academy before the War remains unclear, as does the extent to which it required editing before publication or who contributed to the final published version and how. Istorija kotarskih uskoka remains one of the most important collections of sources for the history of Morlach Dalmatia in the second half of the $17^{\text {th }}$ and the first half of the $18^{\text {th }}$ centuries, so the implications of the aforementioned questions are manifold.

Key words: Vladan Desnica, Boško Desnica, historiography, Uskoks

\section{$\cos$}

\section{Izvori}

Godišnjak XLVIII 1938, Srpska kraljevska akademija, Beograd 1939. /ćir./

Godišnjak LV 1948, Srpska akademija nauka, Beograd 1951. /ćir./

Godišnjak LVII 1950, Srpska akademija nauka, Beograd 1951. /ćir./

Osobna ostavština Vladana Desnice (OOVD), kut. Prepiska do 1945. 


\section{Literatura}

Sima Ćirković i Rade Minaldžıć, Enciklopedija srpske istoriografije, Beograd 1997.

Boško Desnica, Istorija kotarskih uskoka, sv. I: 1646 - 1684, Beograd 1950. /ćir./; sv. II: 1684 1749, Beograd 1951. /ćir.l

Boško Desnica, Sabrana djela (priredio i uvodni tekst napisao Milorad Savić), Zagreb 2008. /ćir. i lat.l

Boško Desnica, „Zadranin Šimun Ljubavac. Jedan dalmatinski erudit XVII vijeka“, Glasnik Primorske banovine, 1/1938., br. 1, 173-181.

Vladan Desnica, „Mirko Korolija i njegov kraj“, Magazin Sjeverne Dalmacije, sv. II/1935., 117129. /ćir./

Vladan Desnica, Hotimično iskustvo: diskurzivna proza Vladana Desnice. Knjiga prva (prir. Dušan Marinković), Zagreb 2006.

Vladan Desnica, Hotimično iskustvo: diskurzivna proza Vladana Desnice. Knjiga druga (prir. Dušan Marinković), Zagreb 2006.

Magazin Sjeverne Dalmacije, sv. I/1934., sv. II/1935. /ćir. i lat./

Tea Maynew, Dalmatia between Ottoman and Venetian Rule. Contado di Zara 1645 - 1718, Roma 2008.

Giuseppe Praga, Scritti sulla Dalmazia (a cura di Egidio Ivetic), tomo I-III, Rovigno 2014.

Drago Roksandić, „Kud koje žure brzi kraci / a vode svi u bespuće’: Vladan Desnica u Splitu od 1935. do 1941. godine“, Split i Vladan Desnica 1918. - 1945.: umjetničko stvaralaštvo izmedu kulture i politike. Zbornik radova sa znanstvenog skupa Desničini susreti 2015. (ur. Drago Roksandić i Ivana Cvijović Javorina), Zagreb 2016., 415-458.

Jorjo TaDić, Pisma i uputstva Dubrovačke Republike, knj. I., Beograd 1935. Ićir./

Drago Roksandić, „Vladan Desnica i Magazin Sjeverne Dalmacije: književnik i (ne)moć tradicije“, Vladan Desnica i Split 1920. - 1945. Zbornik radova sa znanstvenog skupa Desničini susreti 2014. (ur. Drago Roksandić i Ivana Cvijović Javorina), Zagreb 2015., 181-234. 